\title{
Hormonal manipulations in the 5-day timed artificial insemination protocol to optimize estrous cycle synchrony and fertility in dairy heifers
}

\author{
F. S. Lima, ${ }^{*}$ E. S. Ribeiro, ${ }^{*}$ R. S. Bisinotto, ${ }^{*}$ L. F. Greco, ${ }^{*}$ N. Martinez, ${ }^{*}$ M. Amstalden, $\dagger$ W. W. Thatcher, \\ and J. E. P. Santos*1 \\ *Department of Animal Sciences, University of Florida, Gainesville 32611 \\ †Department of Animal Sciences, Texas A\&M University, College Station 77843
}

\begin{abstract}
Objectives were to determine the effects of $\mathrm{GnRH}$ at the initiation of the 5-d timed artificial insemination (AI) program combined with 2 injections of $\mathrm{PGF}_{2 \alpha}$ on ovarian responses and pregnancy per $\mathrm{AI}(\mathrm{P} / \mathrm{AI})$ in dairy heifers, and the role of progesterone concentrations on $\mathrm{LH}$ release and ovulation in response to GnRH. In study 1 , heifers received a controlled internal drug release (CIDR) insert containing $1.38 \mathrm{~g}$ of progesterone on $\mathrm{d}$ 0 , an injection of $25 \mathrm{mg}$ of $\mathrm{PGF}_{2 \alpha}$ and CIDR removal on d 5, and an injection of $100 \mu \mathrm{g}$ GnRH concurrently with AI on d 8. Heifers were assigned to receive no additional treatment (control; $\mathrm{n}=559$ ) or an injection of $\mathrm{GnRH}$ on d 0 and a second injection of $\mathrm{PGF}_{2 \alpha}$ on $\mathrm{d}$ $6(\mathrm{G} 2 \mathrm{P} ; \mathrm{n}=547)$. In study 2 , all heifers were treated as described for the control in study 1 , and were allocated to receive no additional treatment (control; $\mathrm{n}=723$ ), an injection of $\mathrm{PGF}_{2 \alpha}$ on d $6(\mathrm{NG} 2 \mathrm{P} ; \mathrm{n}=703)$, or an injection of $\mathrm{GnRH}$ on $\mathrm{d} 0$ and an injection of $\mathrm{PGF}_{2 \alpha}$ on d $6(\mathrm{G} 2 \mathrm{P} ; \mathrm{n}=718)$. In study 3 , heifers received a CIDR on $\mathrm{d} 7$ after ovulation and were assigned randomly to a low-progesterone (LP; $\mathrm{n}=6$ ) treatment in which 2 injections of $25 \mathrm{mg}$ of $\mathrm{PGF}_{2 \alpha}$ each were administered $12 \mathrm{~h}$ apart, on $\mathrm{d} 7$ and 7.5 after ovulation, or to a high-progesterone ( $\mathrm{HP} ; \mathrm{n}=12)$ treatment in which no $\mathrm{PGF}_{2 \alpha}$ was administered. On d 8, heifers received $100 \mu \mathrm{g}$ of GnRH and blood was sampled at every 15 min from -30 to 180 min relative to the $\mathrm{GnRH}$ for assessment of LH concentrations. Additionally, 94 heifers were assigned to LP or HP and ovulation in response to GnRH was evaluated. In study $1, \mathrm{P} / \mathrm{AI}$ was greater for G2P than for the control on d 32 (59.4 vs. $53.5 \%)$ and 60 after AI (56.6 vs. $51.3 \%$ ). In study 2, administration of $\mathrm{GnRH}$ on d 0 increased the proportion of heifers with a new corpus luteum on $\mathrm{d} 5$ (control $=21.9$ vs. $\mathrm{NG} 2 \mathrm{P}=20.1$ vs. $\mathrm{G} 2 \mathrm{P}=34.4 \%)$. Administration of a second $\mathrm{PGF}_{2 \alpha}$ increased the proportion of heifers with
\end{abstract}

Received June 2, 2013.

Accepted July 16, 2013

${ }^{1}$ Corresponding author: jepsantos@ufl.edu progesterone $<0.5 \mathrm{ng} / \mathrm{mL}$ at $\mathrm{AI}$ (control $=83.1$ vs. $\mathrm{NG} 2 \mathrm{P}=93.0$ and $\mathrm{G} 2 \mathrm{P}=87.2 \%$ ). Pregnancy per AI was greater for G2P than for control and NG2P on d 32 (control $=52.9$ vs. $\mathrm{NG} 2 \mathrm{P}=55.0$ vs. $\mathrm{G} 2 \mathrm{P}=61.7 \%)$ and $60($ control $=49.0$ vs. $\mathrm{NG} 2 \mathrm{P}=51.6$ vs. $\mathrm{G} 2 \mathrm{P}=59.1 \%)$. In study 3, HP attenuated LH release and reduced ovulation (19.0 vs. $48.4 \%$ ) in response to $\mathrm{GnRH}$ compared with LP. Combining GnRH and 2 doses of $\mathrm{PGF}_{2 \alpha}$ in the 5-d timed AI protocol improved follicle turnover, luteolysis, and P/AI in heifers. Elevated concentrations of progesterone suppressed LH release and are linked with the low ovulatory response to the initial GnRH treatment of the protocol.

Key words: 5-d timed artificial insemination, dairy heifer, luteolysis, ovulation

\section{INTRODUCTION}

Reproductive efficiency in dairy heifers affects age at first calving, which has a major impact on rearing costs and subsequent productive life (Gabler et al., 2000; Ettema and Santos, 2004). Most dairy operations in the United States use AI after observed estrus to manage reproduction in heifers (NAHMS, 2009). Nevertheless, advances in protocols for synchronization of the estrous cycle have supported the use of timed AI as an alternative method to manipulate reproductive cycles and improve economics when detection of estrus is less than 70\% (Ribeiro et al. 2012b). Recent studies have consistently reported pregnancy per AI (P/AI) ranging from 50 to $60 \%$ in dairy heifers subjected to the 5-d timed AI program (Rabaglino et al., 2010; Lima et al., 2011), which are comparable to those observed in heifers inseminated at detected estrus (Kuhn et al., 2006). Further optimization of such programs to either simplify or improve fertility will likely increase acceptance by dairy producers.

Ovulation in response to the initial GnRH injection in timed AI programs enhances synchrony of the estrous cycle, shortens follicle dominance, and improves embryo quality and P/AI (Vasconcelos et al., 1999; Chebel et al., 2006; Cerri et al., 2009a). Nevertheless, 
only 15 to $35 \%$ of heifers ovulate when treated with GnRH at random stages of the estrous cycle (Stevenson et al., 2008; Lima et al., 2011). In addition, heifers that ovulate in response to the initial $\mathrm{GnRH}$ will have a newly formed corpus luteum $(\mathbf{C L})$, which is generally refractory to a single treatment with $\mathrm{PGF}_{2 \alpha}$ on $\mathrm{d} 5$ of the cycle (Rowson et al., 1972; Henricks et al., 1974). Eliminating the first GnRH reduced ovulation at the beginning of the synchronization protocol, but increased the proportion of heifers that underwent luteolysis at AI when a single $\mathrm{PGF}_{2 \alpha}$ injection was used (Lima et al. 2011). Because the benefits associated with follicle turnover were offset by a less-effective CL regression, $\mathrm{P} / \mathrm{AI}$ did not differ between heifers that received or did not receive $\mathrm{GnRH}$ at the initiation of the timed AI program (Lima et al. 2011). These results indicate that the initial $\mathrm{GnRH}$ is not necessary when a single $\mathrm{PGF}_{2 \alpha}$ is used, which simplifies and reduce costs associated with the synchronization protocol.

Results from lactating dairy cows subjected to the 5 -d timed AI program indicate that the use of 2 injections of $\mathrm{PGF}_{2 \alpha}$ administered $24 \mathrm{~h}$ apart improved CL regression and P/AI (Santos et al., 2010), particularly when ovulation to initial GnRH was high (Ribeiro et al., 2012a). Shorter intervals between $\mathrm{PGF}_{2 \alpha}$ treatments, ranging from 7 to $8 \mathrm{~h}$, have been shown to increase $\mathrm{P} /$ AI compared with a single injection in beef cows (Kasimanickam et al., 2009), although preliminary results in dairy heifers did not confirm such benefit (Rabaglino et al., 2010). Therefore, it is reasonable to speculate that the combination of the initial GnRH and the administration of $\mathrm{PGF}_{2 \alpha}$ on $\mathrm{d} 5$ and 6 of the protocol will improve follicle turnover and luteal regression, which are expected to increase $\mathrm{P} / \mathrm{AI}$.

The differences in catabolism of steroid hormones (Sangsritavong et al., 2002) explain the almost 1.5 $\mathrm{ng} / \mathrm{mL}$ greater progesterone concentration in heifers than lactating cows during mid-diestrus (Sartori et al., 2004). In fact, the increase in progesterone concentrations with a controlled internal drug release (CIDR) insert is expected to be greater in nonlactating ( $\mathrm{Zu}$ luaga and Williams, 2008) than in lactating cows (Cerri et al., 2009b). Progesterone affects LH secretion, which might compromise ovulatory response to $\mathrm{GnRH}$ treatment, which might partially explain the low ovulatory response to GnRH in dairy heifers. Results from beef heifers support this idea (Colazo et al., 2008; Dias et al., 2010).

It was hypothesized that a combination of $\mathrm{GnRH}$ at the initiation of the 5-d timed AI and injections of $\mathrm{PGF}_{2 \alpha}$ on $\mathrm{d} 5$ and 6 of the protocol improves the synchrony of the estrous cycle and fertility in dairy heifers. Furthermore, it was hypothesized that elevated concentrations of progesterone compromise the release of $\mathrm{LH}$ and ovulation in response to a GnRH injection in dairy heifers. Study 1 was designed to compare a simplified 5 -d timed AI protocol with a protocol that is expected to optimize $\mathrm{P} / \mathrm{AI}$ by inducing ovulation and optimizing regression of newly formed CL. Study 2 was designed to evaluate the effects of $\mathrm{GnRH}$ at the initiation of 5 -d timed AI program combined with 2 injections of $\mathrm{PGF}_{2 \alpha}$ on ovarian responses and fertility. Finally, the objectives of study 3 were to assess LH release and ovulation in response to $\mathrm{GnRH}$ in dairy heifers with low or high concentrations of progesterone in plasma.

\section{MATERIALS AND METHODS}

The University of Florida Institute of Food and Agricultural Sciences Animal Research Committee (Gainesville) approved all procedures in the 3 studies reported.

\section{Study 1}

Heifers, Diets, and Housing. A total of 1,106 nulliparous Holstein and crossbred Holstein-Jersey heifers at an average $( \pm \mathrm{SD})$ of $14.0 \pm 2.1 \mathrm{mo}$ of age from 2 farms in north central Florida were enrolled in the study between March and June 2010. Crossbred heifers $(\mathrm{n}=231)$ were located only in farm 2 . Four hundred and fifty-seven heifers received their first insemination, whereas the remaining 649 heifers were diagnosed nonpregnant on d 32 after insemination and resynchronized to receive their second AI. Heifers in both locations were managed on pasture with access to portable shades and trees. Heifers were fed a TMR once daily formulated to meet or exceed the nutritional requirements of Holstein heifers weighing $360 \mathrm{~kg}$ and gaining $0.8 \mathrm{~kg} / \mathrm{d}$ (NRC, 2001). The diet consisted of a mixture of lactating cow ration orts, Bermuda grass silage, wet brewers grain, and a mineral and vitamin supplement. For administration of hormonal treatments, insemination, and pregnancy examination, heifers were moved to an open-sided barn with self-locking stations in farm 1 or to a palpation rail in farm 2 .

Experimental Design and Treatments. All heifers received a CIDR insert containing $1.38 \mathrm{~g}$ of progesterone (Eazi-Breed CIDR Cattle Insert; Zoetis Inc., Madison, NJ) on d 0, an i.m. injection of $25 \mathrm{mg}$ of $\mathrm{PGF}_{2 \alpha}$ (dinoprost tromethamine; Lutalyse sterile solution; Zoetis Inc.) and CIDR removal on d 5, and an i.m. injection of $100 \mu \mathrm{g}$ of $\mathrm{GnRH}$ (gonadorelin hydrochloride; Factrel; Zoetis Inc.) concurrently with AI on d 8. On d 0 , heifers were blocked according to number of AI (first or second) and then age and, within each block, they were allocated randomly to receive no additional treatment (control; $\mathrm{n}=559$ ) or an injection of $\mathrm{GnRH}$ on $\mathrm{d}$ 0 and a second injection of $\mathrm{PGF}_{2 \alpha}$ on $\mathrm{d} 6(\mathbf{G} \mathbf{2 P}, \mathrm{n}=$ 

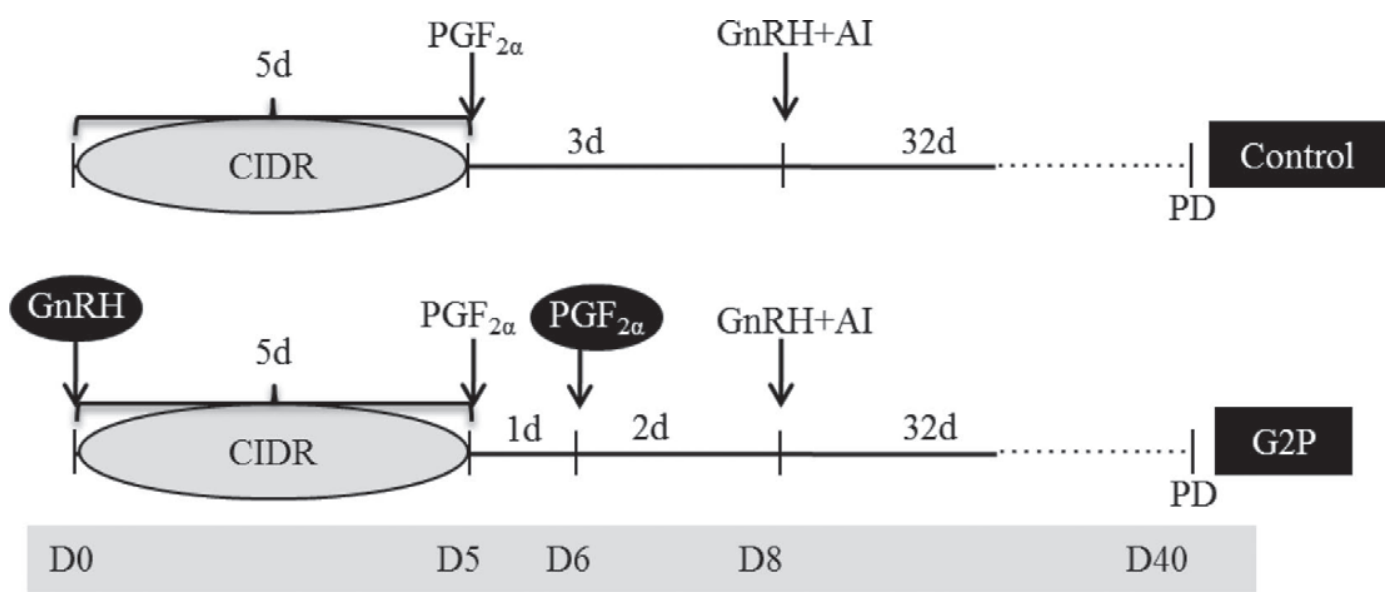

Figure 1. Diagram of activities in study 1. All heifers received a controlled internal drug release (CIDR) insert (containing $1.38 \mathrm{~g}$ of progesterone) on d 0 , an injection of $\mathrm{PGF}_{2 \alpha}$ and CIDR removal on d 5, and an injection of GnRH concurrently with AI on d 8. Control $=$ no additional treatment $(\mathrm{n}=559) ; \mathrm{G} 2 \mathrm{P}=$ additional injection of $\mathrm{GnRH}$ on $\mathrm{d} 0$ and a second injection of $\mathrm{PGF}_{2 \alpha}$ on $\mathrm{d} 6(\mathrm{n}=547) ; \mathrm{PD}=$ pregnancy diagnosis; D0, D5, D6, D8, and D40 = study d 0, 5, 6, 8, and 40, respectively.

547 ; Figure 1). On d 5 and 6, heifers had their tailheads painted using paint sticks (All-Weather Paintstik; LACO Industries Inc., Chicago, IL). Expression of estrus at AI was evaluated based on removal of the tail chalk on $\mathrm{d} 8$. Inseminations were performed by 11 technicians with semen from 6 Holstein and 6 Jersey sires.

Pregnancy Diagnosis and Calculation of P/AI and Pregnancy Loss. Pregnancy was diagnosed $32 \mathrm{~d}$ after AI by transrectal ultrasonography of the uterus using a portable ultrasound unit equipped with a 7.5$\mathrm{MHz}$ transrectal probe (Easi-Scan; BCF Technologies USA Ltd. LLC, Rochester, MN). The visualization of an amniotic vesicle containing an embryo with heartbeat was used as the determinant of pregnancy. Pregnant heifers on d 32 were reexamined by transrectal palpation of uterine contents on d 60 after AI. Pregnancy per AI was calculated by dividing the number of heifers diagnosed pregnant on d 32 or 60 after AI by the number of heifers receiving AI. Pregnancy loss was calculated as the number of heifers that lost their pregnancy between d 32 and 60 after AI divided by the number of heifers diagnosed pregnant on d 32 after AI.

\section{Study 2}

Heifers, Diets, and Housing. A total of 2,144 nulliparous Holstein heifers with an average $( \pm \mathrm{SD})$ of $13.5 \pm 1.0 \mathrm{mo}$ of age from a single farm in north central Florida were enrolled in the study between July 2010 and April 2011. A total of 1,723 heifers received their first insemination, whereas the remaining 421 heifers were diagnosed nonpregnant on d 32 after their first AI and resynchronized to receive the second AI. Heifers were managed and fed as described in study 1 . For ad- ministration of hormonal treatments, ultrasonography examination, blood sampling, insemination, and pregnancy diagnosis, heifers were moved to an open-sided barn with self-locking stations.

Experimental Design and Treatments. All heifers received a CIDR insert containing $1.38 \mathrm{~g}$ of progesterone on d 0, an i.m. injection of $25 \mathrm{mg}$ of $\mathrm{PGF}_{2 \alpha}$ and CIDR removal on $\mathrm{d} 5$, and an i.m. injection of $100 \mu \mathrm{g}$ of GnRH concurrently with AI on d 8. On d 0 , heifers were blocked by number of AI (first or second) and then age and, within each block, they were allocated randomly to receive no additional treatment (control; $\mathrm{n}=723$ ), an additional injection of $\mathrm{PGF}_{2 \alpha}$ on d 6 (NG2P; $\mathrm{n}=703)$, or an injection of $\mathrm{GnRH}$ on d 0 and an additional injection of $\mathrm{PGF}_{2 \alpha}$ on d $6(\mathbf{G} \mathbf{2 P} ; \mathrm{n}=$ 718; Figure 2). Estrus at AI was detected as described in study 1 . Inseminations were performed by 10 technicians with semen from 10 Holstein and 3 Jersey sires.

Ultrasonography of Ovaries and Evaluation of Ovulatory Responses. Ovaries from a subset of 623 heifers were scanned on study d 0 and 5 and the presence and location of CL $>15 \mathrm{~mm}$ and follicles $\geq 10$ $\mathrm{mm}$ in diameter were recorded. Ovulation at the beginning of the timed AI program was considered when the heifer had a follicle $\geq 10 \mathrm{~mm}$ on $\mathrm{d} 0$ and a newly formed CL was observed in the same ovary on d 5. Heifers with follicles $<10 \mathrm{~mm}$ on study d 0 but with a new CL on study d 5 were considered to have a new CL, but ovulated before study d 0 .

Blood Sampling and Analysis of Progesterone Concentrations. Blood was sampled from 610 of the same subset of 623 heifers evaluated for ovulation described previously. Blood samples were collected on d 8 by puncture of the median coccygeal vein or artery 

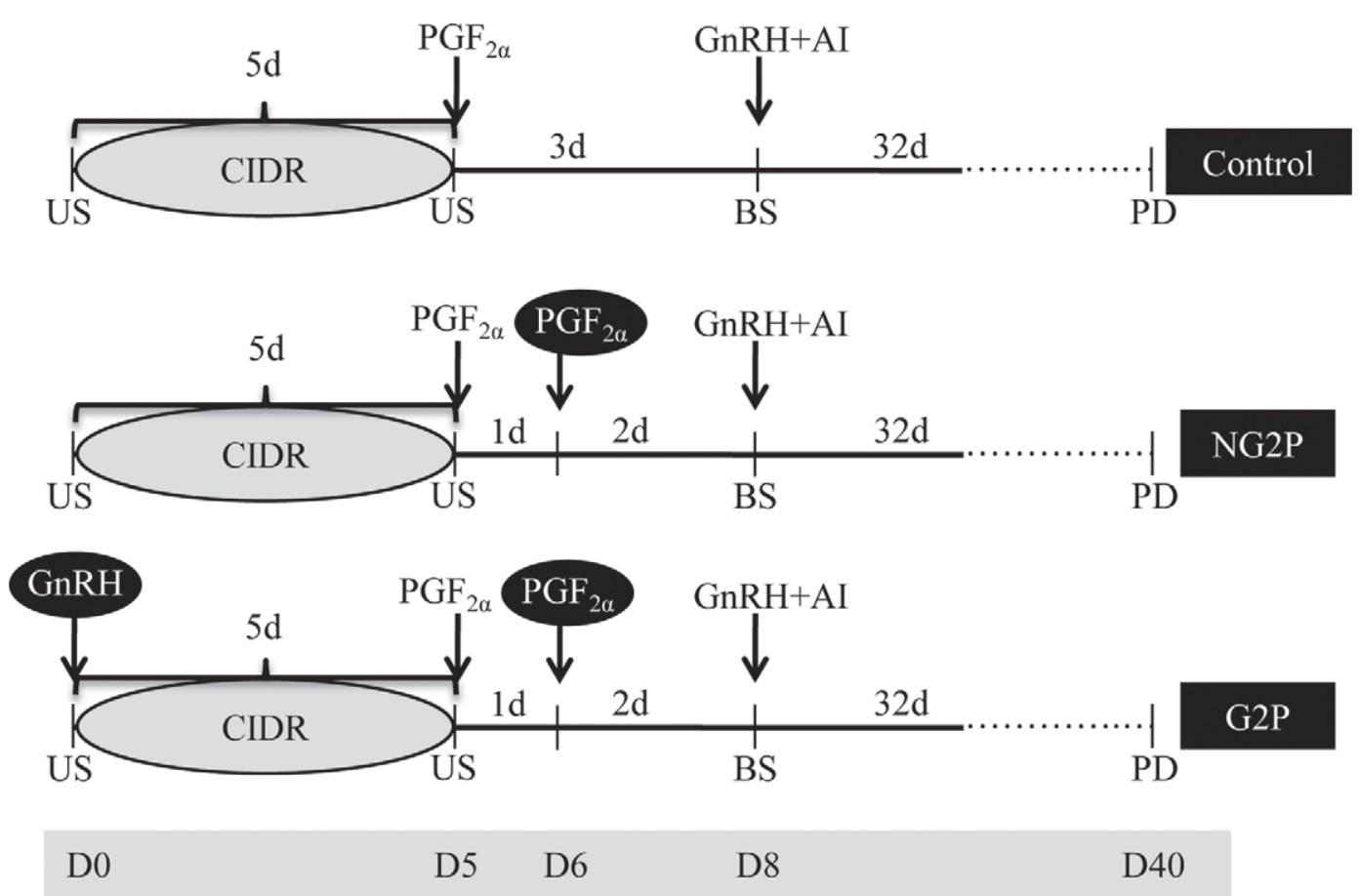

Figure 2. Diagram of activities in study 2. All heifers received a controlled internal drug release (CIDR) insert (containing $1.38 \mathrm{~g}$ of progesterone) on $\mathrm{d} 0$, an injection of $\mathrm{PGF}_{2 \alpha}$ and CIDR removal on $\mathrm{d} 5$, and an injection of $\mathrm{GnRH}$ concurrently with timed AI on $\mathrm{d} 8$. Control $=$ no additional treatment $(\mathrm{n}=723) ; \mathrm{NG} 2 \mathrm{P}=$ a second injection of $\mathrm{PGF}_{2 \alpha}$ on d $6(\mathrm{n}=703) ; \mathrm{G} 2 \mathrm{P}=$ an injection of GnRH on d 0 and a second injection of $\mathrm{PGF}_{2 \alpha}$ on d $6(\mathrm{n}=718)$. US = ultrasound; $\mathrm{BS}=$ blood sample for analysis of progesterone; $\mathrm{PD}=$ pregnancy diagnosis; D0, D5, D6, $\mathrm{D} 8$, and D40 = study d $0,5,6,8$, and 40 , respectively.

using evacuated tubes (Becton Dickinson, Franklin Lakes, NJ) containing $\mathrm{K}_{2}$ EDTA for plasma separation. Samples were placed immediately on ice and kept refrigerated until arrival to the laboratory. Blood tubes were centrifuged at $2,000 \times g$ for $15 \mathrm{~min}$ at $5^{\circ} \mathrm{C}$, and an aliquot of $2 \mathrm{~mL}$ of plasma was frozen at $-20^{\circ} \mathrm{C}$ until analysis. Concentration of progesterone in plasma was determined in all samples by RIA using a commercial kit (Coat-a-Count; Siemens Healthcare Diagnostics Inc., Los Angeles, CA). The sensitivity of the assay was $0.05 \mathrm{ng} / \mathrm{mL}$ calculated at 2 standard deviations below the mean counts per minute at maximum binding. All samples were analyzed in a single assay. Two plasma samples with progesterone concentrations of 1.5 and $2.5 \mathrm{ng} / \mathrm{mL}$ were included throughout the sequence of samples in the assay for quality control. The intraassay coefficients of variation were 2.5 and $2.9 \%$ for the samples containing 1.5 and $2.5 \mathrm{ng} / \mathrm{mL}$, respectively.

Three different cut-off values for plasma concentrations of progesterone at AI were used to determine luteolysis, progesterone $<1.0,<0.50$, and $<0.30 \mathrm{ng} / \mathrm{mL}$. These 3 values were selected based on the traditional threshold used to indicate CL regression $(1 \mathrm{ng} / \mathrm{mL})$, or based on concentration of progesterone at AI that have been used as cut-off values that best predicted P/AI (Rabaglino et al., 2010; Santos et al., 2010).
Pregnancy Diagnosis and Calculation of $P /$ AI and Pregnancy Loss. Pregnancy was diagnosed 32 and $60 \mathrm{~d}$ after AI, as described in study 1. Similarly, $\mathrm{P} / \mathrm{AI}$ and pregnancy loss were calculated as described for study 1. Of all 2,144 heifers, 26 did not have a pregnancy diagnosis performed (control: $\mathrm{n}=12$; NG2P: $\mathrm{n}$ $=7 ; \mathrm{G} 2 \mathrm{P}: \mathrm{n}=7$ ) because they were moved to another farm before d 32 after AI.

\section{Study 3}

Experimental Design and Treatments. Holstein nulliparous heifers from the University of Florida Dairy Unit had their ovaries scanned and those having a CL $\geq 15 \mathrm{~mm}$ and at least 1 follicle $\geq 10 \mathrm{~mm}$ in diameter received an injection of $\mathrm{PGF}_{2 \alpha}$. Heifers had their tailheads painted and were observed daily for signs of estrus based on removal of the tail chalk. Heifers detected in estrus between 48 and $72 \mathrm{~h}$ after the injection of $\mathrm{PGF}_{2 \alpha}$ had their ovaries scanned to map the ovarian follicles. Ovaries were scanned again 24 and $48 \mathrm{~h}$ after estrus and the disappearance of 1 or more follicles $\geq 10$ $\mathrm{mm}$ was considered ovulation, which was assumed to have occurred on the day preceding the scanning when the dominant follicle was no longer visible by ultrasonography. Only heifers that ovulated within $48 \mathrm{~h}$ of 
detected estrus were included in the study. The day of ovulation was considered study d 0 . Heifers were assigned randomly to either a low- $(\mathbf{L P} ; \mathrm{n}=6)$ or high-progesterone $(\mathbf{H P} ; \mathrm{n}=12$ ) treatment (Figure 3 ). All heifers received a CIDR insert on d 7 after ovulation and those assigned to $\mathrm{LP}$ received 2 injections of $\mathrm{PGF}_{2 \alpha}$ $12 \mathrm{~h}$ apart beginning at CIDR insertion. On $\mathrm{d} 8$, all heifers received an i.m. injection of $100 \mu \mathrm{g}$ of $\mathrm{GnRH}$ (gonadorelin diacetate tetrahydrate; Cystorelin; Merial Ltd., Iselin, NJ). An additional group of 94 nulliparous Holstein heifers were randomly assigned to the same treatments in a ratio of 1 to 2 (i.e., $31 \mathrm{LP}$ and $63 \mathrm{HP}$ heifers). An injection of $100 \mu \mathrm{g}$ of $\mathrm{GnRH}$ was administered on d 8 and ovaries were scanned on d 7, 8, and 12 to characterize ovulation in response to GnRH.

Blood Sampling and Analyses of Concentrations of $\mathbf{L H}$ and Progesterone. The release of $\mathrm{LH}$ induced by the injection of $100 \mu \mathrm{g} \mathrm{GnRH}$ was evaluated in the 18 heifers subjected to LP and HP treatments. A 14-gauge $\times 14-\mathrm{cm}$ indwelling catheter (AbbocathT; Hospira Inc., Lake Forest, IL) was placed in the left jugular vein for the duration of blood sampling. Samples were collected at $-30,-15,0,15,30,45,60$, $75,90,105,120,135,150,165,180,240$, and $300 \mathrm{~min}$ relative to the injection of GnRH. Before each sampling, approximately $8 \mathrm{~mL}$ of blood were drawn and discarded for cleansing of the catheter. Samples were then collected using a 10-mL syringe and transferred into evacuated tubes (Becton Dickinson) for subsequent serum separation. After sampling, the catheters were flushed with heparinized solution (30 USP heparin sodium; Sigma-Aldrich, Saint Louis, MO) to avoid clogging. Samples were immediately place on ice, remaining there for $30 \mathrm{~min}$, and then placed at room temperature for $30 \mathrm{~min}$ before centrifugation for serum separation. Tubes were centrifuged at $2,200 \times g$ for $15 \mathrm{~min}$ at $4^{\circ} \mathrm{C}$ for serum separation. Serum samples were frozen at $-20^{\circ} \mathrm{C}$ until later analysis.

Concentrations of $\mathrm{LH}$ in serum were determined by RIA as previously reported (McVey and Williams, 1991). Highly purified ovine LH (AFP-8614B, NIDDKoLH-I-4; National Hormone and Pituitary Program, Harbor-UCLA Medical Center, Torrance, CA) was used as both the reference preparation and as iodinated tracer. The primary antiserum used was produced in rabbits immunized against ovine LH (AFP-192279, NIDK-anti-oLH-1; National Hormone and Pituitary Program). This antiserum displays similar crossreactivity between highly purified preparations of ovine (NIDDK-I-2) and bovine (AFP11743B) LH and does not cross-react with other pituitary hormones. Sensitivity of the assay was $0.1 \mathrm{ng} / \mathrm{mL}$ and the intra- and interassay coefficients of variation averaged 11.9 and $10.4 \%$, respectively.

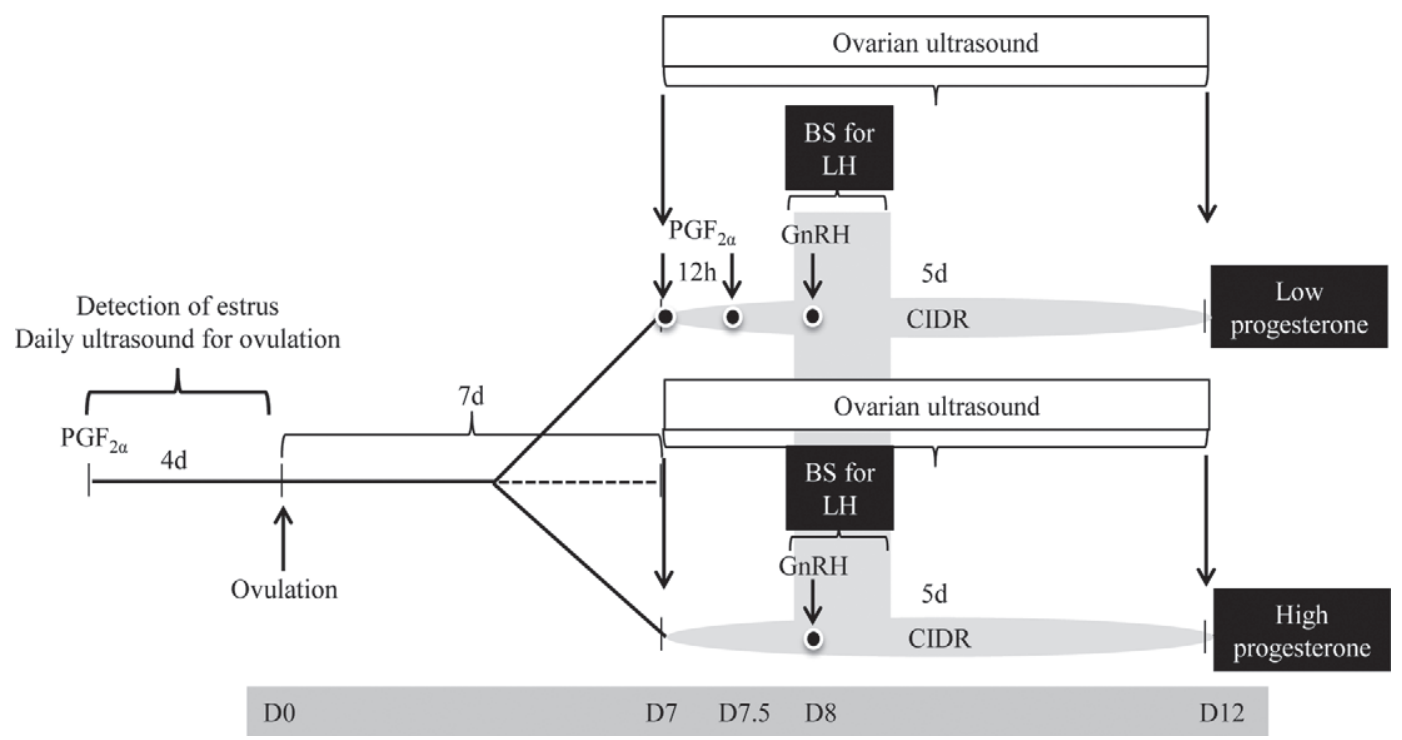

Figure 3. Diagram of activities in study 3. Heifers had their estrous cycles synchronized with $\mathrm{PGF}_{2 \alpha}$ and those in estrus were evaluated for ovulation (study d 0). Heifers received a controlled internal drug release (CIDR) insert (containing $1.38 \mathrm{~g}$ of progesterone) on d 7 and were assigned to low-progesterone ( $\mathrm{LP} ; \mathrm{n}=6$ ) treatment in which 2 injections of $\mathrm{PGF}_{2 \alpha}$ were administered $12 \mathrm{~h}$ apart on $\mathrm{d} 7.0$ and 7.5 , or highprogesterone ( $\mathrm{HP} ; \mathrm{n}=12$ ) treatment in which no $\mathrm{PGF}_{2 \alpha}$ was administered. All heifers received $100 \mu \mathrm{g}$ of $\mathrm{GnRH}$ on $\mathrm{d} 8$ and blood was sampled every $15 \mathrm{~min}$ from -30 to $180 \mathrm{~min}$ and at 240 and $300 \mathrm{~min}$ relative to the $\mathrm{GnRH}$ injection for assessment of $\mathrm{LH}$ concentrations. BS $=$ blood sample; $\mathrm{GnRH}=$ injection of $100 \mu \mathrm{g}$ of gonadorelin hydrochloride; $\mathrm{PGF}_{2 \alpha}=$ injection of $25 \mathrm{mg}$ of dinoprost as tromethamine salt; D0, D7, D7.5, D8, and D12 = study d 0,7,7.5, 8, and 12, respectively. An additional 94 heifers were assigned to LP $(\mathrm{n}=31)$ and HP $(\mathrm{n}=63)$ treatments and ovulation in response to GnRH was determined by scanning the ovaries on $\mathrm{d} 7,8$, and 12 . 
An additional blood sample was collected immediately before the injection of $\mathrm{GnRH}$ and transferred to evacuated tubes (Becton Dickinson) containing $\mathrm{K}_{2}$ EDTA for plasma separation. Plasma was separated, stored, and assayed for progesterone concentration as described in study 1 . Concentrations of progesterone in plasma were analyzed in the same assay described in study 2 with intraassay coefficients of variation of 2.5 and $2.9 \%$ for known samples containing 1.5 and $2.5 \mathrm{ng} /$ $\mathrm{mL}$, respectively.

\section{Statistical Analyses}

Power analyses were performed to calculate sample sizes in all 3 studies using Minitab 16 software (Minitab Inc., State College, PA). Sample sizes were calculated for studies 1 and 2 to allow sufficient experimental units to detect a difference of 6 percentage units in $\mathrm{P} /$ AI between treatments $[\alpha=0.05 ; \beta$ (the probability of a type II error) $=0.20 ; 2$-tailed test $]$. The expected $\mathrm{P} / \mathrm{AI}$ for first and second AI combined was of $58 \%$ for $\mathrm{G} 2 \mathrm{P}$ and $52 \%$ for the remaining treatments, based on previous studies (Rabaglino et al., 2010; Lima et al., 2011). Under these assumptions, a minimum of 540 and 636 experimental units per treatment were deemed necessary in studies 1 , which had 2 treatments, and 2 , which had 3 treatments, respectively. Because of potential attrition, additional heifers were added to all treatments in both studies. In study 3 , the sample size was calculated to allow sufficient experimental units to detect a difference of 30 percentage units in ovulatory response to $\mathrm{GnRH}(\alpha=0.05 ; \beta=0.20)$. The ovulatory response was anticipated to increase from $20 \%$ in HP to $50 \%$ in LP, based on previous studies with the 5 -d timed AI protocol (Lima et al., 2011).

Categorical data were analyzed by logistic regression using PROC GLIMMIX of SAS version 9.3 (SAS/ STAT; SAS Institute Inc., Cary, NC) fitting a binary distribution. Treatment was forced in the final models, but covariates and the interaction between treatment and covariates were sequentially removed from the model if $P>0.10$.

In study 1 , the model for detection of estrus included the effects of treatment, breed, farm, number of AI, age of heifer (<13 mo vs. 13 to 15 mo vs. $>15$ mo), and the interactions of treatment and breed, treatment and farm, and treatment and number of AI. The models for $\mathrm{P} / \mathrm{AI}$ and pregnancy loss included the effects of treatment, breed, farm, number of AI, age of heifer, sire, AI technician, and the interactions of treatment and breed, treatment and farm, and treatment and number of AI. In study 2 , the models for analyses of ovarian responses to treatments, proportion of heifers with progesterone at AI below 1 of 3 cut-off points $(<1.0,<0.50$, and
$<0.30 \mathrm{ng} / \mathrm{mL}$ ), and proportion of heifers in estrus at AI included the effects of treatment, age of heifer $(<13$ mo vs. 13 to 14 mo vs. $>14 \mathrm{mo}$ ), presence of CL on d 0 , and interaction between treatment and presence of CL on $\mathrm{d} 0$. The models for $\mathrm{P} / \mathrm{AI}$ and pregnancy loss included the effects of treatment, number of AI, age of heifer, sire, AI technician, and interaction between treatment and AI number.

Concentrations of progesterone at $\mathrm{AI}$ in study 2 were analyzed by ANOVA using PROC GLM of SAS. The model included the effects of treatment, age group, and presence of CL on study d 0 . In study 3 , concentrations of LH were analyzed by ANOVA for repeated measurements using PROC MIXED of SAS. The values for LH concentration at $-30,-15$, and 0 min was averaged for each individual heifer and used as a covariate. The model included the effects of treatment, time, and the interaction between treatment and time, with heifer nested within treatment as the random term for test of effects of treatment. The covariance structure that resulted in the smallest Akaike information criterion was selected for the model. Differences with $P \leq 0.05$ were considered significant and those with $0.05<P \leq$ 0.10 were considered tendencies.

\section{RESULTS}

\section{Study 1}

The proportion of heifers detected in estrus on the day of timed AI did not differ between treatments and averaged $76.8 \%$ (Table 1$)$. A greater $(P<0.001)$ proportion of heifers were detected in estrus at $\mathrm{AI}$ in farm 1 compared with farm 2 (81.5 vs. $62.1 \%$ ). No interactions were observed between treatment and other independent variables for detection of estrus at AI.

Pregnancy per AI on d 32 was greater $(P=0.04)$ for G2P than for control heifers (Table 1). Similarly, the proportion of pregnant heifers on d 60 tended $(P=0.06)$ to be greater in G2P than in control heifers. Although $\mathrm{P} / \mathrm{AI}$ was greater $(P=0.02)$ in farm 1 compared with farm 2 on d 32 (57.3 vs. $54.0 \%)$ and 60 after AI (54.4 vs. $52.7 \%$ ), no interaction between treatment and farm was observed for P/AI. Pregnancy loss was not affected by treatment or by the interactions between treatment and other independent variables.

\section{Study 2}

A CL visible by ultrasonography was observed in $80.4 \%$ of the heifers on $\mathrm{d} 0$, indicating that the majority were cyclic. As anticipated, ovulation on d 0 and the presence of a new CL on d 5 were greater $(P \leq 0.01)$ for G2P than for control or NG2P heifers (Table 2). 
Table 1. Effect of the initial GnRH injection and 2 doses of $\mathrm{PGF}_{2 \alpha}$ on fertility responses of dairy heifers subjected to the 5-d timed AI program (study 1)

\begin{tabular}{|c|c|c|c|c|}
\hline \multirow[b]{2}{*}{ Item } & \multicolumn{2}{|c|}{ Treatment, ${ }^{1} \%$ (no./total no.) } & \multirow[b]{2}{*}{$\operatorname{AOR}(95 \% \mathrm{CI})^{2}$} & \multirow[b]{2}{*}{$P$-value } \\
\hline & Control & G2P & & \\
\hline Estrus at $\mathrm{AI}^{3}$ & $76.7(429 / 559)$ & $76.9(421 / 547)$ & $1.03(0.77-1.38)$ & 0.83 \\
\hline $\begin{array}{l}\text { Pregnant } \\
\text { d } 32\end{array}$ & $53.5(299 / 559)$ & $59.4(325 / 547)$ & $1.28(1.01-1.63)$ & 0.04 \\
\hline $\begin{array}{l}\text { d } 60 \\
\text { Pregnancy loss }{ }^{4}\end{array}$ & $\begin{array}{c}51.3(287 / 559) \\
4.0(12 / 299)\end{array}$ & $\begin{array}{r}56.6(309 / 546) \\
4.6(15 / 324)\end{array}$ & $\begin{array}{l}1.24(0.98-1.58) \\
1.15(0.53-2.52)\end{array}$ & $\begin{array}{l}0.07 \\
0.72\end{array}$ \\
\hline
\end{tabular}

${ }^{1}$ Control $=\mathrm{d}-0$ controlled internal drug release (CIDR) insertion, $\mathrm{d}-5 \mathrm{PGF}_{2 \alpha}$ injection and removal of CIDR, and d-8 GnRH injection and timed AI; G2P $=\mathrm{d}-0 \mathrm{GnRH}$ injection and CIDR insertion, $\mathrm{d}-5 \mathrm{PGF}_{2 \alpha}$ injection and removal of CIDR, d- $6 \mathrm{PGF}_{2 \alpha}$ injection, and d-8 GnRH injection and timed AI.

${ }^{2} \mathrm{AOR}=$ adjusted odds ratio. Control is the reference for comparison.

${ }^{3}$ Evaluated based on removal of tail chalk on the d of AI.

${ }^{4}$ Calculated as the number of heifers that lost their pregnancies between $\mathrm{d} 32$ and 60 after AI divided by the number of heifers pregnant on d 32. One pregnant heifer from G2P left the study before reconfirmation of pregnancy on d 60 .

Ovulation on study d 0 was greater $(P<0.01)$ for heifers without a CL $(\mathrm{n}=122)$ than in those with a CL (n $=501$ ) on $\mathrm{d} 0$ (45.9 vs. $10.4 \%$ ). Although ovulation at the initiation of the timed AI program was increased by the administration of $\mathrm{GnRH}$, the proportion of heifers with a visible CL on study d 5 did not differ between treatments. The proportion of heifers with progesterone concentration at AI below the cutoffs of 0.30 and 0.50 $\mathrm{ng} / \mathrm{mL}$ was less for control than NG2P and G2P heifers (Table 2). A tendency $(P=0.09)$ for interaction between treatment and new CL was observed for luteolysis based on progesterone $<0.50 \mathrm{ng} / \mathrm{mL}$ on study d 8 .
This interaction was because treatments with $2 \mathrm{PGF}_{2 \mathrm{a}}$ injections increased luteolysis in heifers with a new CL compared with controls, but no difference was observed for those without a new CL. For control, the proportions of heifers with progesterone $<0.50 \mathrm{ng} / \mathrm{mL}$ were 85.7 and $73.9 \%$ for those without and with a new CL; for NG2P, the same proportions were 93.7 and $90.2 \%$, and for G2P, they were 85.0 and $91.4 \%$. No interactions existed between treatments and any other independent variables for any of the ovarian responses in study 2 .

Treatment affected $(P=0.02)$ the proportion of heifers in estrus at AI (Table 3). Detection of estrus was

Table 2. Effect of the initial GnRH injection and 2 doses of $\mathrm{PGF}_{2 \alpha}$ on ovarian responses in dairy heifers subjected to the 5-d timed AI program (study 2)

\begin{tabular}{|c|c|c|c|c|}
\hline \multirow[b]{2}{*}{ Item } & \multicolumn{3}{|c|}{ Treatment, ${ }^{1} \%$ (no./total no.) } & \multirow[b]{2}{*}{$P$-value } \\
\hline & Control & NG2P & $\mathrm{G} 2 \mathrm{P}$ & \\
\hline \multicolumn{5}{|l|}{ Study d 0} \\
\hline Follicle $\geq 10 \mathrm{~mm}$ & $95.2(200 / 210)$ & $95.1(194 / 204)$ & $91.0(190 / 209)$ & 0.76 \\
\hline Presence of $\mathrm{CL}^{2}$ & $81.0(170 / 210)$ & $82.3(168 / 204)$ & $78.0(163 / 209)$ & 0.83 \\
\hline Ovulation $^{3}$ & $13.8(29 / 210)^{\mathrm{b}}$ & $11.8(24 / 204)^{\mathrm{b}}$ & $26.3(55 / 209)^{\mathrm{a}}$ & 0.001 \\
\hline \multicolumn{5}{|l|}{ Study d 5} \\
\hline Presence of CL & $88.6(186 / 210)$ & $91.2(186 / 204)$ & $88.5(185 / 209)$ & 0.60 \\
\hline Presence of a new $\mathrm{CL}^{4}$ & $21.9(46 / 210)^{\mathrm{b}}$ & $20.1(41 / 204)^{\mathrm{b}}$ & $34.4(72 / 209)^{\mathrm{a}}$ & 0.01 \\
\hline \multicolumn{5}{|l|}{ Progesterone on study d 8} \\
\hline$<1.0 \mathrm{ng} / \mathrm{mL}^{5}$ & $95.2(197 / 207)$ & $97.0(194 / 200)$ & $97.5(198 / 203)$ & 0.39 \\
\hline$<0.5 \mathrm{ng} / \mathrm{mL}$ & $83.1(172 / 207)^{\mathrm{b}}$ & $93.0(186 / 200)^{\mathrm{a}, \mathrm{A}}$ & $87.2(177 / 203)^{\mathrm{B}}$ & 0.01 \\
\hline$<0.3 \mathrm{ng} / \mathrm{mL}$ & $62.8(130 / 207)^{\mathrm{b}, \mathrm{B}}$ & $75.0(150 / 200)^{\mathrm{a}}$ & $70.9(144 / 203)^{\mathrm{A}}$ & 0.02 \\
\hline
\end{tabular}

${ }_{\mathrm{a}, \mathrm{b}}$ Different lowercase superscripts within a row indicate significant differences $(P<0.05)$.

${ }^{\mathrm{A}, \mathrm{B}}$ Different capital superscripts within a row indicate tendencies to differ $(P=0.07)$.

${ }^{1}$ Control $=\mathrm{d}-0$ controlled internal drug release $(\mathrm{CIDR})$ insertion, $\mathrm{d}-5 \mathrm{PGF}_{2 \alpha}$ injection and removal of CIDR, and d-8 GnRH injection and AI; NG2P $=$ d-0 CIDR insertion, d-5 PGF ${ }_{2 \alpha}$ injection and removal of CIDR, d- 6 $\mathrm{PGF}_{2 \alpha}$ injection, and d- 8 GnRH injection and $\mathrm{AI} ; \mathrm{G} 2 \mathrm{P}=\mathrm{d}-0 \mathrm{GnRH}$ injection and CIDR insertion, d-5 PGF $\mathrm{P}_{2 \alpha}$ injection and removal of CIDR, d- $6 \mathrm{PGF}_{2 \alpha}$ injection, and d-8 GnRH injection and AI.

${ }^{2} \mathrm{CL}=$ corpus luteum.

${ }^{3}$ Proportion of heifers with a follicle $\geq 10 \mathrm{~mm}$ on d 0 and a new CL on d 5 in the same location.

${ }^{4}$ Proportion of heifers with a new CL on d 5 regardless of follicles $\geq 10 \mathrm{~mm}$ on $\mathrm{d} 0$.

${ }^{5}$ Thirteen of the 623 heifers evaluated had no blood sample collected on the day of AI. 
Table 3. Effect of the initial GnRH injection and 2 doses of $\mathrm{PGF}_{2 \alpha}$ on fertility responses in dairy heifers subjected to the 5-d timed AI program (study 2)

\begin{tabular}{|c|c|c|c|c|}
\hline \multirow[b]{2}{*}{ Item } & \multicolumn{3}{|c|}{ Treatment, ${ }^{1} \%$ (no./total no.) } & \multirow[b]{2}{*}{$P$-value } \\
\hline & Control & NG2P & $\mathrm{G} 2 \mathrm{P}$ & \\
\hline & $72.6(525 / 723)^{\mathrm{b}}$ & $74.4(523 / 703)^{\mathrm{B}}$ & $78.6(564 / 718)^{\mathrm{a}, \mathrm{A}}$ & 0.02 \\
\hline \multirow{3}{*}{$\begin{array}{l}\text { Pregnant }^{3} \\
\text { d } 32 \\
\text { d } 60 \\
\text { Pregnancy loss }\end{array}$} & $52.9(376 / 711)^{\mathrm{b}}$ & $55.0(383 / 696)^{\mathrm{b}}$ & $61.7(439 / 711)^{\mathrm{a}}$ & 0.003 \\
\hline & $49.0(348 / 711)^{\mathrm{b}}$ & $51.6(359 / 696)^{\mathrm{b}}$ & $59.1(420 / 711)^{\mathrm{a}}$ & 0.001 \\
\hline & $7.5(28 / 376)^{\mathrm{B}}$ & $6.3(24 / 383)^{\mathrm{AB}}$ & $4.3(19 / 439)^{\mathrm{A}}$ & 0.15 \\
\hline \multicolumn{5}{|c|}{$\begin{array}{l}\overline{\mathrm{a}, \mathrm{b}} \text { Different lowercase superscripts within a row indicate significant differences }(P<0.05) \text {. } \\
\mathrm{A}, \mathrm{B} \text { Different capital superscripts within a row indicate tendencies to differ }(P<0.10) \text {. }\end{array}$} \\
\hline \multicolumn{5}{|c|}{$\begin{array}{l}{ }^{1} \text { Control }=\mathrm{d}-0 \text { controlled internal drug release (CIDR) insertion, } \mathrm{d}-5 \mathrm{PGF}_{2 \alpha} \text { injection and removal of CIDR, } \\
\text { and } \mathrm{d}-8 \mathrm{GnRH} \text { injection and } \mathrm{AI} \text {; NG2P }=\mathrm{d}-0 \mathrm{CIDR} \text { insertion, } \mathrm{d}-5 \mathrm{PGF}_{2 \alpha} \text { injection and removal of CIDR, } \mathrm{d}-6 \\
\mathrm{PGF}_{2 \alpha} \text { injection, and } \mathrm{d}-8 \mathrm{GnRH} \text { injection and } \mathrm{AI} \text {; } \mathrm{G} 2 \mathrm{P}=\mathrm{d}-0 \mathrm{GnRH} \text { injection and CIDR insertion, } \mathrm{d}-5 \mathrm{PGF}_{2 \alpha} \\
\text { injection and removal of CIDR, d- } 6 \mathrm{PGF}_{2 \alpha} \text { injection, and } \mathrm{d} 8 \mathrm{GnRH} \text { injection and AI. } \\
{ }^{2} \text { Evaluated based on removal of tail chalk on the day of AI. } \\
{ }^{3} \text { Twelve control heifers, } 7 \mathrm{NG} 2 \mathrm{P} \text { heifers, and } 7 \mathrm{G} 2 \mathrm{P} \text { heifers did not have a pregnancy diagnosis performed. } \\
{ }^{4} \text { Calculated as the number of heifers that lost their pregnancies between d } 32 \text { and } 60 \text { after AI divided by the } \\
\text { number of heifers pregnant on } \mathrm{d} 32 \text {. }\end{array}$} \\
\hline
\end{tabular}

greater $(P<0.01)$ for $\mathrm{G} 2 \mathrm{P}$ than control heifers, and tended $(P=0.06)$ to be greater for G2P than NG2P heifers. No difference was observed between control and NG2P heifers. Pregnancies per AI on d 32 and 60 after insemination were greater $(P<0.01)$ for $\mathrm{G} 2 \mathrm{P}$ than control and NG2P heifers. Heifers detected in estrus $(\mathrm{n}=1,612)$ on the day of AI had greater $(P<0.001)$ $\mathrm{P} / \mathrm{AI}$ on $\mathrm{d} 32(58.6$ vs. $50.7 \%)$ and on d 60 (56.7 vs. $48.8 \%)$ than those not in estrus $(\mathrm{n}=532)$. Heifers receiving their second insemination had greater $(P=$ $0.05) \mathrm{P} / \mathrm{AI}$ on $\mathrm{d} 60$ than heifers receiving their first insemination (57.6 vs. 52.2). Pregnancy loss tended ( $P$ $=0.06$ ) to be less for G2P than control heifers (Table $3)$. Heifers receiving their first $\mathrm{AI}$ had greater $(P=$ $0.03)$ pregnancy loss than heifers receiving their second AI (6.7 vs. $2.9 \%)$.

When $\mathrm{P} / \mathrm{AI}$ were analyzed in the subset of 623 heifers with ovarian ultrasound and progesterone concentration at $\mathrm{AI}$, an interaction $(P=0.03)$ between number of $\mathrm{PGF}_{2 \alpha}$ injections and new $\mathrm{CL}$ was observed for $\mathrm{P} / \mathrm{AI}$ on d 32 and 60 after insemination. For heifers without a new $\mathrm{CL}$, the number of $\mathrm{PGF}_{2 \alpha}$ injections (control vs. $\mathrm{NG} 2 \mathrm{P}+\mathrm{G} 2 \mathrm{P})$ did not $(P=0.36)$ influence $\mathrm{P} / \mathrm{AI}$ on d 32 (control $=59.3$ vs. $\mathrm{NG} 2 \mathrm{P}+\mathrm{G} 2 \mathrm{P}=54.9 \%)$, but for those heifers with a new CL on d 5 of the timed AI protocol, administration of 2 doses of $\mathrm{PGF}_{2 \alpha}(\mathrm{NG} 2 \mathrm{P}+$ $\mathrm{G} 2 \mathrm{P})$ increased $(P<0.05) \mathrm{P} / \mathrm{AI}$ compared with control $(62.8$ vs. $45.7 \%)$. The same response was observed on d 60 after AI; in heifers without a new CL, the number of $\mathrm{PGF}_{2 \alpha}$ injections did not $(P=0.53)$ influence $\mathrm{P} / \mathrm{AI}$ (control $=54.9$ vs. $\mathrm{NG} 2 \mathrm{P}+\mathrm{G} 2 \mathrm{P}=51.9 \%$ ); however, in those with a new $\mathrm{CL}$, administration of 2 doses of $\mathrm{PGF}_{2 \alpha}$ increased $(P<0.05) \mathrm{P} / \mathrm{AI}$ compared with control (61.1 vs. $43.5 \%)$.

\section{Study 3}

As expected, the concentration of progesterone on $\mathrm{d}$ 8 was less $(P=0.01)$ for LP than HP heifers (Table 4$)$. The elevated concentration of progesterone in the HP treatment reduced $(P=0.04)$ the mean concentration of LH in serum compared with LP heifers. A tendency $(P=0.07)$ of interaction between treatment and time relative to GnRH injection was observed for LH concentrations. Serum concentrations of LH were less $(P<$ $0.05)$ from 45 to 135 min after the injection of GnRH in HP compared with LP treatment (Figure 4). Furthermore, HP treatment tended to reduce $(P=0.09)$ the peak concentration of $\mathrm{LH}$ in plasma compared with LP treatment. The interval from GnRH injection to peak of LH concentration did not differ between treatments. Finally, HP heifers had reduced $(P=0.01)$ incidence of ovulation in response to GnRH compared with LP heifers.

\section{DISCUSSION}

The results of the current study clearly support the concept that increased ovulation with administration of $\mathrm{GnRH}$ at the initiation of the protocol, combined with improved luteolysis at insemination, by using 2 doses of $\mathrm{PGF}_{2 \alpha}$, are necessary to optimize $\mathrm{P} / \mathrm{AI}$ in dairy heifers subjected to the 5 -d timed AI program. These results are consistent with our hypothesis and clarify unanswered questions from findings of a previous study (Lima et al., 2011). Previously, administration of GnRH on d 0 of the 5-d timed AI protocol increased ovulation compared with no GnRH administration, but did not improve $\mathrm{P} / \mathrm{AI}$ in heifers receiving a single 
Table 4. Effects of concentration of progesterone in plasma on LH release and ovulation in response to GnRH injection in dairy heifers (study 3 )

\begin{tabular}{lccc}
\hline & \multicolumn{2}{c}{ Treatment $^{1}$} & \\
\cline { 2 - 3 } Item & LP & HP & $P$-value \\
\hline Progesterone, $^{2} \mathrm{ng} / \mathrm{mL}$ & $3.14 \pm 0.88$ & $7.35 \pm 0.67$ & 0.001 \\
LH response to GnRH, ng/mL & & & \\
Mean & $16.3 \pm 2.3$ & $10.1 \pm 1.8$ & 0.04 \\
Peak & $31.3 \pm 2.3$ & $19.2 \pm 4.1$ & 0.09 \\
Minutes after GnRH to peak & $81.4 \pm 14.4$ & $76.3 \pm 11.1$ & 0.78 \\
Ovulation response to GnRH, ${ }^{3}$ \% (no./total no.) & $48.4(15 / 31)$ & $19.0(12 / 63)$ & 0.001 \\
\hline
\end{tabular}

${ }^{1} \mathrm{LP}=$ low-progesterone heifers received a controlled internal drug release (CIDR) insert and $2 \mathrm{PGF}_{2 \alpha}$ injections $12 \mathrm{~h}$ apart on $\mathrm{d} 7$ after ovulation and were challenged with $\mathrm{GnRH}$ on d 8; HP = high-progesterone heifers received a CIDR insert and were challenged with GnRH on $\mathrm{d} 8$.

${ }^{2}$ Progesterone and LH concentrations were evaluated in 18 heifers (6 LP and $12 \mathrm{HP}$ ).

${ }^{3}$ Ovulation was evaluated in 94 heifers.

dose of $\mathrm{PGF}_{2 \alpha}$ (Lima et al., 2011). This lack of benefit was suggested to be caused by the inability of a single injection of $\mathrm{PGF}_{2 \alpha}$ to fully regress newly formed CL to optimize fertility.

Study 1 was designed as a practical study to evaluate 2 breeding strategies for dairy heifers, one with minimum intervention without GnRH on d 0 and with a single $\mathrm{PGF}_{2 \alpha}$ injection on $\mathrm{d} 5$, and another treatment expected to optimize P/AI by improving follicle turnover and CL regression. Although the study design does not permit identification of the mechanisms for improved fertility in heifers receiving G2P compared with controls, it is clear that a simplified version of the 5-d timed AI protocol, as implemented in control heifers, does not maximize P/AI. Based on the results of study 1 , it was unclear if benefits in $\mathrm{P} / \mathrm{AI}$ in heifers were derived from the combined improved follicle turnover and luteolysis or if just an improved luteolysis would be sufficient to improve P/AI. Therefore, study 2 was designed to investigate if a combined improved follicle turnover and luteolysis was necessary to maximize $\mathrm{P} / \mathrm{AI}$ in dairy heifers.

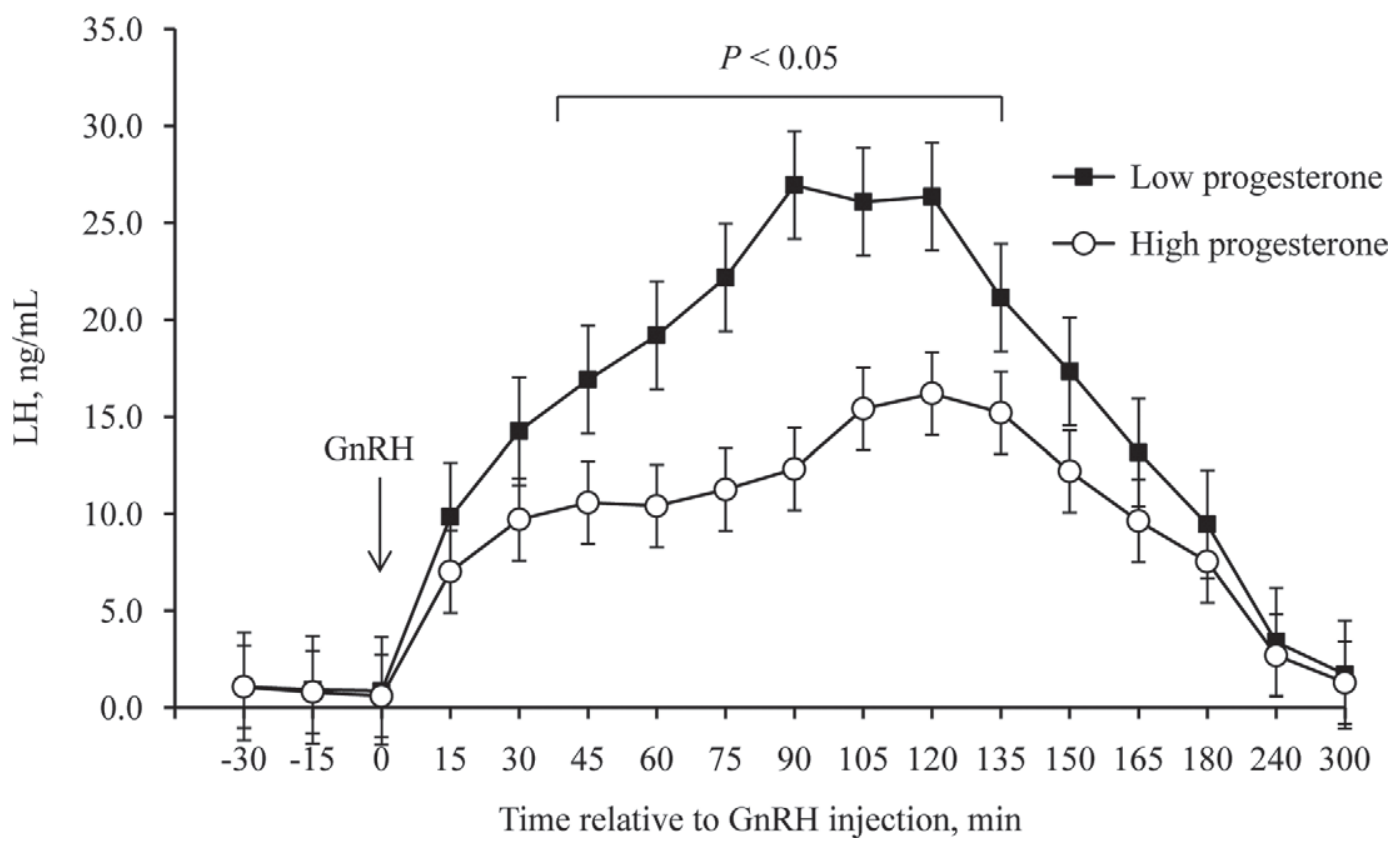

Figure 4. Effect of progesterone concentration on the LH release in response to an injection of $100 \mu \mathrm{g}$ of gonadorelin hydrochloride (GnRH). Heifers had the estrous cycle synchronized and ovulation was study d 0. All heifers received a controlled internal drug release (CIDR) insert containing progesterone on d 7 and $100 \mu \mathrm{g}$ of gonadorelin hydrochloride $(\mathrm{GnRH})$. Low progesterone (LP): heifers received PGF $2 \alpha$ on d 7.0 and 7.5. High progesterone (HP): no $\mathrm{PGF}_{2 \alpha}$ was administered. Blood was sampled for LH every 15 min from -30 to 180 min relative to GnRH injection and at 240 and 300 min. Effects: treatment: $P=0.04$, minute relative to GnRH: $P<0.001$, and interaction between treatment and minute relative to GnRH: $P=0.07$. 
Dairy cows that ovulate to the initial GnRH of the timed AI program have enhanced overall synchrony of the estrous cycle (Vasconcelos et al., 1999; Rutigliano et al., 2008), which shortens the period of follicle dominance and improves embryo quality (Cerri et al., 2009a). This follicle response is beneficial to fertility in dairy cows (Vasconcelos et al., 1999; Rutigliano et al., 2008; Santos et al., 2010). For instance, the results of a previous study in dairy heifers suggested that follicle turnover was not as critical as it appears to be in dairy cows to improve fertility, when only $1 \mathrm{PGF}_{2 \alpha}$ injection was used in the 5-d timed AI program (Lima et al., 2011). However, it is possible that the potential benefits of improved follicle turnover were offset by reduced luteolysis obtained with a single treatment with $\mathrm{PGF}_{2 \alpha}$. In fact, the 5-d interval between $\mathrm{GnRH}$ and $\mathrm{PGF}_{2 \alpha}$ injections might limit adequate luteolysis when a newly formed CL is present.

The refractoriness of the early CL with fewer than 5 $\mathrm{d}$ of development to a single $\mathrm{PGF}_{2 \alpha}$ treatment has been reported (Rowson et al., 1972; Henricks et al. 1974), and one solution to overcome this problem is the use of multiple $\mathrm{PGF}_{2 \alpha}$ treatments (Santos et al., 2010; Ribeiro et al., 2012a). Although multiple doses of $\mathrm{PGF}_{2 \alpha}$ have been shown to successfully induce luteolysis even in cows with CL of fewer than $5 \mathrm{~d}$ of development (Beal et al., 1980), the use of $2 \mathrm{PGF}_{2 \alpha}$ injections did not always improve fertility (Cruppe et al., 2010; Rabaglino et al., 2010). One possibility to explain the lack of benefit of 2 doses of $\mathrm{PGF}_{2 \alpha}$ in the 5 -d timed AI program is a poor ovulatory response to $\mathrm{GnRH}$ when the protocol is initiated, so only a small proportion of animals have newly formed CL. The mechanism of refractoriness of the early CL to $\mathrm{PGF}_{2 \alpha}$ has not been elucidated completely. Tsai and Wiltbank (1998) suggested that early $\mathrm{CL}$, in spite of having functional $\mathrm{PGF}_{2 \alpha}$ receptors, is incapable of inducing intraluteal synthesis of $\mathrm{PGF}_{2 \alpha}$ via prostaglandin-endoperoxidase synthase 2, increasing expression of monocyte chemoattractant protein 1 , and inhibiting progesterone production through steroidogenic acute regulatory protein. Additionally, Miyamoto et al. (2009) suggested a site-restricted action of $\mathrm{PGF}_{2 \alpha}$, depending on the stage of the estrous cycle. In the midcycle CL (d 8 to 12), $\mathrm{PGF}_{2 \alpha}$ induces an acute increase in blood flow in the periphery of the CL concurrent with expression of endothelial nitric oxide synthase, but the same phenomenon is not observed in the early-cycle CL (d 4). Moreover, Atli et al. (2012) reported that although the initial pulse of $\mathrm{PGF}_{2 \alpha}$ upregulates mRNA expression of many pathways related to luteolysis, the second and later pulses of $\mathrm{PGF}_{2 \alpha}$ are actually responsible for a distinct pattern of gene expression that results in luteolysis. Therefore, either multiple doses of $\mathrm{PGF}_{2 \alpha}$ are needed to fully regress the newly formed CL, or the fact that the second dose of $\mathrm{PGF}_{2 \alpha}$ was administered on d 6 after the GnRH might have allowed some CL to become more mature and responsive to the luteolytic effects of prostaglandin. It is important to indicate that when no GnRH was administered, as in the control and NG2P treatments, the second dose of $\mathrm{PGF}_{2 \alpha}$ did not improve P/AI despite the increase in luteolysis. These results reinforce the need to combine follicle turnover with adequate CL regression to optimize fertility in the 5-d timed AI protocol for dairy heifers.

Low ovulatory response to GnRH in dairy heifers has been demonstrated by others (Stevenson et al., 2008; Lima et al., 2011). One of the factors that might affect ovulation to GnRH is the diameter of the dominant follicle (Sartori et al., 2001), which is known to be related to the expression of $\mathrm{LH}$ receptors on granulosa cells (Xu et al., 1995). Granulosa cells acquire LH receptors at the time of follicle deviation, approximately $3 \mathrm{~d}$ after the emergence of a follicular wave, when the dominant follicle achieves $8.5 \mathrm{~mm}$ in diameter. However, most heifers in previous studies had follicles of at least $10 \mathrm{~mm}$ in diameter when $\mathrm{GnRH}$ was administered (Martinez et al., 1999; Lima et al., 2011). Another possibility is that approximately $50 \%$ of the heifers have 3 waves of follicle development (Bisinotto and Santos, 2011), which limits the period of follicle dominance and the opportunity to have a follicle responsive to a $\mathrm{GnRH} / \mathrm{LH}$ surge to induce ovulation. Interestingly, dairy heifers without a CL had greater ovulation to GnRH than heifers with a CL in a previous study (Lima et al., 2011). This finding suggests that high progesterone concentration might be another impediment to ovulation, particularly when heifers are in mid-luteal phase and receive a CIDR insert as in the 5-d timed AI protocol. The negative effects of progesterone on $\mathrm{LH}$ release in response to GnRH have been demonstrated in beef heifers, mature beef cows, and dairy cows (Colazo et al, 2008; Dias et al., 2010; Giordano et al., 2012). The results of the current study confirm the hypothesis of negative effects of progesterone on LH release and ovulation in dairy heifers treated with GnRH. Therefore, the present study clarifies that induction of follicle turnover with $\mathrm{GnRH}$ in dairy heifers subjected to the 5-d timed AI protocol is inhibited by elevated concentrations of progesterone, which attenuates LH release.

\section{CONCLUSIONS}

Increased follicle turnover at initiation of 5-d timed AI program by using GnRH combined with 2 doses of $\mathrm{PGF}_{2 \alpha}$ administered on $\mathrm{d} 5$ and 6 to optimize luteolysis was a successful strategy to optimize $\mathrm{P} / \mathrm{AI}$ in dairy heifers. Results of the current study demonstrate similar concepts of previous work with lactating dairy cows, 
reinforcing the need for synchronization protocols to incorporate physiological principles to optimize fertility in dairy heifers. Follicle turnover by inducing ovulation with GnRH, although low in dairy heifers, was beneficial to fertility. However, the benefit of $\mathrm{GnRH}$ to optimize fertility requires 2 doses of $\mathrm{PGF}_{2 \alpha}$ administered $24 \mathrm{~h}$ apart to increase regression of a newly formed CL. The P/AI of approximately $60 \%$ obtained in the current study supports the use of the 5-d timed AI protocol as an alternative breeding program for reproductive management of heifers when detection of estrus is not used. Finally, it was demonstrated that high concentrations of progesterone when GnRH was administered suppressed the LH release and impaired ovulation. Further research is needed to determine if additional increase in ovulation to the initial GnRH of the 5-d timed AI protocol can further improve fertility in dairy heifers.

\section{ACKNOWLEDGMENTS}

The authors thank the owner and staff of Alliance Dairies (Trenton, FL) for the use of their cows and facilities. Our appreciation is extended to Nilo Francisco of Alliance Dairies. We thank Eric Diepersloot of the University of Florida Dairy Unit (Hague).

\section{REFERENCES}

Atli, M. O., W. R. W. Bender, V. Mehta, M. R. Bastos, W. Luo, C. M. Vezina, and M. C. Wiltbank. 2012. Patterns of gene expression in the bovine corpus luteum following repeated intrauterine infusions of low doses of prostaglandin F2alpha. Biol. Reprod. 86:130.

Beal, W. E., R. A. Milvae, and W. Hansel. 1980. Oestrous cycle length and plasma progesterone concentrations following administration of prostaglandin $\mathrm{F}_{2 \alpha}$ early in the bovine oestrous cycle. J. Reprod. Fertil. 59:393-396.

Bisinotto, R. S., and J. E. P. Santos. 2011. The use of endocrine treatments to improve pregnancy rates in cattle. Reprod. Fertil. Dev. $24: 258-266$.

Cerri, R. L. A., H. M. Rutigliano, R. G. Bruno, and J. E. P. Santos. 2009b. Progesterone concentration, follicular development and induction of cyclicity in dairy cows receiving intravaginal progesterone inserts. Anim. Reprod. Sci. 110:56-70.

Cerri, R. L. A., H. M. Rutigliano, R. C. Chebel, and J. E. P. Santos. 2009a. Period of dominance of the ovulatory follicle influences embryo quality in lactating dairy cows. Reproduction 137:813-823.

Chebel, R. C., J. E. P. Santos, R. L. A. Cerri, H. M. Rutigliano, and R. G. S. Bruno. 2006. Reproduction in dairy cows following progesterone insert presynchronization and resynchronization protocols. J. Dairy Sci. 89:4205-4219.

Colazo, M. G., J. P. Kastelic, H. Davis, M. D. Rutledge, M. F. Martinez, J. A. Small, and R. J. Mapletoft. 2008. Effects of plasma progesterone concentrations on LH release and ovulation in beef cattle given GnRH. Domest. Anim. Endocrinol. 34:109-117.

Cruppe, L. H., L. A. Souto, M. Maquivar, P. Gunn, M. L. Mussard, D. Wolfenson, A. V. Pires, G. A. Bridges, and M. L. Day. 2010 Use of two coincident doses of $\mathrm{PGF}_{2 \alpha}$ with the 5-d CO-Synch plus CIDR estrous synchronization program. J. Anim. Sci. 88(E-Suppl. 2):768. (Abstr.)

Dias, F. C. F., M. G. Colazo, J. P. Kastelic, R. J. Mapletoft, G. P. Adams, and J. Singh. 2010. Progesterone concentration, estradiol pretreatment, and dose of gonadotropin-releasing hormone affect gonadotropin-releasing hormone-mediated luteinizing hormone release in beef heifers. Domest. Anim. Endocrinol. 39:155-162.

Ettema, J. F., and J. E. P. Santos. 2004. Impact of age at calving on lactation, reproduction, health, and income in first parity Holsteins on commercial farms. J. Dairy Sci. 87:2730-2742.

Gabler, M. T., P. R. Tozer, and A. J. Heinrichs. 2000. Development of a cost analysis spreadsheet for calculating the costs to raise a replacement dairy heifer. J. Dairy Sci. 83:1104-1109.

Giordano, J. O., P. M. Fricke, J. N. Guenther, G. Lopes Jr., M. M. Herlihy, A. B. Nascimento, and M. C. Wiltbank. 2012. Effect of progesterone on magnitude of the luteinizing hormone surge induced by two different doses of GnRH in lactating dairy cows. J. Dairy Sci. 95:3781-3793.

Henricks, D. M., J. T. Long, J. R. Hill, and J. F. Dickey. 1974. The effect of prostaglandin $\mathrm{F}_{2 \alpha}$ during various stages of the oestrous cycle of beef heifers. J. Reprod. Fertil. 41:113-120.

Kasimanickam, R., M. L. Day, J. S. Rudolph, J. B. Hal, and W. D. Whittier. 2009. Two doses of prostaglandin improve pregnancy rates to timed-AI in a 5-day progesterone-based synchronization protocol in beef cows. Theriogenology 71:762-767.

Kuhn, M. T., J. L. Hutchison, and G. R. Wiggans. 2006. Characterization of Holstein heifer fertility in the United States. J. Dairy Sci. 89:4907-4920

Lima, F. S., H. Ayres, M. G. Favoreto, R. S. Bisinotto, L. F. Greco, E. S. Ribeiro, P. S. Baruselli, C. A. Risco, W. W. Thatcher, and J. E. P. Santos. 2011. Effects of gonadotropin-releasing hormone at initiation of the 5-d timed artificial insemination (AI) program and timing of induction of ovulation relative to $\mathrm{AI}$ on ovarian dynamics and fertility of dairy heifers. J. Dairy Sci. 94:4997-5004.

Martinez, M. F., G. P. Adams, D. R. Bergfelt, J. P. Kastelic, and R. J. Mapletoft. 1999. Effect of LH or GnRH on the dominant follicle of the first follicular wave in beef heifers. Anim. Reprod. Sci. $57: 23-33$.

McVey, W. R. Jr., and G. L. Williams. 1991. Mechanical masking of neurosensory pathways at the calf-teat interface: Endocrine, reproductive and lactational features on the suckled anestrous cow. Theriogenology 35:931-941.

Miyamoto, A., K. Shirasuna, and K. Sasahara. 2009. Local regulation of corpus luteum development and regression in the cow: Impact of angiogenic and vasoactive factors. Domest. Anim. Endocrinol. $37: 159-169$.

NAHMS (National Animal Health Monitoring System). 2009. Dairy 2007, Part IV: Reference of Dairy Cattle Health and Management Practices in the United States, 2007. \#N494.0209. Centers for Epidemiology and Animal Health, US Department of Agriculture:Animal and Plant Health Inspection Service:Veterinary Services (USDA:APHIS:VS), Fort Collins, CO.

NRC. 2001. Nutrient Requirements of Dairy Cattle. 7th rev. ed. Natl. Acad. Sci., Washington, DC.

Rabaglino, M. B., C. A. Risco, M.-J. Thatcher, I. H. Kim, J. E. P. Santos, and W. W. Thatcher. 2010. Application of one injection of prostaglandin $\mathrm{F}_{2 \alpha}$ in the five-day Co-Synch + CIDR protocol for estrous synchronization and resynchronization of dairy heifers. J. Dairy Sci. 93:1050-1058.

Ribeiro, E. S., R. S. Bisinotto, M. G. Favoreto, L. T. Martins, R. L. A Cerri, F. T. Silvestre, L. F. Greco, W. W. Thatcher, and J. E. P. Santos. 2012a. Fertility in dairy cows following presynchronization and administering twice the luteolytic dose of prostaglandin $\mathrm{F}_{2 \mathrm{a}}$ as one or two injections in the 5-day timed artificial insemination protocol. Theriogenology 78:273-284.

Ribeiro, E. S., K. N. Galvão, W. W. Thatcher, and J. E. P. Santos. 2012b. Economic aspects of applying reproductive technologies to dairy herds. Anim. Reprod. 9:370-387.

Rowson, L. E., R. Tervit, and A. Brand. 1972. The use of prostaglandins for synchronization of oestrus in cattle. J. Reprod. Fertil. 29:145.

Rutigliano, H. M., F. S. Lima, R. L. A. Cerri, L. F. Greco, J. M. Vilela, V. Magalhães, F. T. Silvestre, W. W. Thatcher, and J. E. P. Santos. 2008. Effects of method of presynchronization and source of 
selenium on uterine health and reproduction in dairy cows. J. Dairy Sci. 91:3323-3336.

Sangsritavong, S., D. K. Combs, R. Sartori, and M. C. Wiltbank. 2002. High feed intake increases blood flow and metabolism of progesterone and estradiol-17ß in dairy cattle. J. Dairy Sci. 85:2831-2842.

Santos, J. E. P., C. D. Narciso, F. Rivera, W. W. Thatcher, and R. C. Chebel. 2010. Effect of reducing the period of follicle dominance in a timed AI protocol on reproduction of dairy cows. J. Dairy Sci. 93:2976-2988.

Sartori, R., P. M. Fricke, J. C. Ferreira, O. J. Ginther, and M. C. Wiltbank. 2001. Follicular deviation and acquisition of ovulatory capacity in bovine follicles. Biol. Reprod. 65:1403-1409.

Sartori, R., J. M. Haughian, R. D. Shaver, G. J. Rosa, and M. C. Wiltbank. 2004. Comparison of ovarian function and circulating steroids in estrous cycles of Holstein heifers and lactating cows. J. Dairy Sci. 87:905-920.

Stevenson, J. L., J. C. Dalton, J. E. P. Santos, R. Sartori, A. Ahmadzadeh, and R. C. Chebel. 2008. Effect of synchronization protocols on follicular development and estradiol and progesterone concentrations of dairy heifers. J. Dairy Sci. 91:3045-3056.
Tsai, S.-J., and M. C. Wiltbank. 1998. Prostaglandin $\mathrm{F}_{2 \alpha}$ regulates distinct physiological changes in early and mid-cycle bovine corpora lutea. Biol. Reprod. 58:346-352.

Vasconcelos, J. L. M., R. W. Silcox, G. J. M. Rosa, J. R. Pursley, and M. C. Wiltbank. 1999. Synchronization rate, size of the ovulatory follicle, and pregnancy rate after synchronization of ovulation beginning on different days of the estrous cycle in lactating dairy cows. Theriogenology 52:1067-1078.

Xu, Z., H. A. Garverick, G. W. Smith, M. F. Smith, S. A. Hamilton, and R. S. Youngquist. 1995. Expression of follicle-stimulating hormone and luteinizing hormone receptor messenger ribonucleic acid in bovine follicles during the first follicular wave. Biol. Reprod. 53:951-957.

Zuluaga, J. F., and G. L. Williams. 2008. High-pressure steam sterilization of previously used CIDR inserts enhances the magnitude of the acute increase in circulating progesterone after insertion in cows. Anim. Reprod. Sci. 107:30-35. 